\title{
EKSTRAKURIKULER DALAM MENGEMBANGKAN DIRI PESERTA DIDIK DI LEMBAGA PENDIDIKAN
}

\author{
Aziza Meria \\ UIN Imam Bonjol Padang \\ email: azizameria2015@yahoo.com
}

\begin{abstract}
Abstrak
Penelitian ini dilatarbelakangi dari keinginan madrasah dalam mengembangkan bakat dan minat peserta didik melalui kegiatan ekstrakurikuler. Seperti kegiatan muhadharah dan kaligrafi peserta didik. Tujuan penelitian ini ingin menggambarkan pelaksanaan, faktor pendukung dan penghambat kegiatan ekstrakurikuler muhadharah dan kaligrafi dalam mengembangkan diri peserta didik. Penelitian ini menggunakan pendekatan kualitatif dengan analisis deskriptif. Sunber data atau informan adalah guru pembina kegiatan ekstrakurikuler, peserta didik kelas VIII dan Kepala Sekolah MTsN Tapan. Adapun teknik pengumpulan data dilakukan melalui observasi, wawancara, dan dokumentasi. Hasil penelitian ini mengungkapkan bahwa: 1) Kegiatan ekstrakurikuler seperti muhadharah ternyata mampu mengembangkan diri peserta didik. Hal itu ditunjukan dengan tumbuhnya rasa percaya diri dan meningkatnya kemampuan komunikasi peserta didik. Kegiatan ekstrakulikuler dalam bentuk kegiatan kaligrafi ternyata dapat menumbuhkan rasa sabar, teliti, dan kreatif. Hal tersebut dibuktikan dengan kemampuan melukis kaligrafi dengan corak yang lebih baik, halus, dan beragam gaya. 2) Peningkatan pengembangan diri peserta didik selain karena faktor dalam diri mereka juga didukung oleh perhatian dan kebijakan kepala sekolah seperti menyediakan fasilitas latihan, dan pelatih yang profesional. Sedangkan kendalanya adalah waktu latihan yang kurang, sarana prasarana pendukung yang belum memadai.
\end{abstract}

Kata Kunci : Ekstrakurikuler, muhadharah, kaligrafi, dan pengembangan diri

\section{PENDAHULUAN}

Manusia pada hakikatnya mempunyai berbagai macam potensi dan ia diberikan kebebasan untuk mengembangkan potensi yang ia sukai (Ramayulis, 2004). Untuk mengembangkan potensi yang dimilikinya atau yang disukai, manusia membutuhkan pendidikan yang dapat menumbuh kembangkan potensi yang ada pada dirinya. Pendidikan bagi manusia merupakan suatu sistem dan cara dalam meningkatkan kualitas kehidupannya di segala bidang, sehingga dalam sepanjang hidup umat manusia di muka bumi ini tidak ada kelompok manusia yang tidak menggunakan pendidikan sebagai alat pembudayaan dan peningkatan kualitas hidupnya (Arifin, 2008).

Orang yang berpendidikan akan mendapat kedudukan yang tinggi di masyarakat. Menuntut ilmu pengetahuan adalah suatu hal yang sangat dianjurkan oleh Allah SWT, dengan ilmu pengetahuan orang dapat memberikan baktinya pada masyarakat dan ilmu manusia berbeda dari makhluk lain. Sehingga secara tidak langsung ia akan mempunyai derajat yang tinggi. Allah SWT berjanji akan mengangkat derajat 
orang yang beriman dan berilmu. Sebagaimana Firman Allah SWT dalam alQur'an surat al-Mujadalah ayat 11, yang artinya:

Hai orang-orang beriman apabila dikatakan kepadamu: "berlapanglapanglah dalam majlis", maka lapangkanlah, niscaya Allah akan memberi kelapangan untukmu. Dan apabila dikatakan: "berdirilah", maka berdirilah kamu, niscaya Allah akan meninggikan derajat orang-orang yang beriman di antaramu dan orang-orang yang diberi ilmu pengetahuan. Dan ssungguhnya Allah mengetahui apa yang kamu kerjakan. (Q.S AlMujadalah/58 : 11)

Menurut Mustafa al Maragy ayat di atas menjelaskan bahwa Allah SWT meninggikan derajat orang-orang mukmin yang mengikuti perintah Allah dan RasulNya, terutama kepada orangorangyang beriman dengan pengetahuan dan berilmu pengetahuan.

Dalam Undang-undang RI No. 20 Tahun 2003 tentang Sistem Pendidikan Nasional pasal 3, Pemerintah Indonesia telah menggariskan bahwa tujuan utama pendidikan adalah untuk mengembangkan kemampuan dan membentuk watak serta peradaban bangsa yang bermartabat dalam rangka mencerdaskan kehidupan bangsa, serta untuk mengembangkan potensi peserta didik supaya menjadi manusia yang beriman dan bertaqwa kepada Tuhan Yang Maha Esa, berakhlak mulia, sehat, berilmu, cakap, kreatif, mandiri dan menjadi warga negara yang demokratis serta bertanggung jawab.

Sementara pendidikan agama sendiri mempunyai kedudukan dan peranan yang sangat penting di dalam pembangunan Nasional sebab pembangunan Nasional adalah pembangunan manusia Indonesia seutuhnya dan pembangunan seluruh masyarakat Indonesia. Keberhasilan pembangunan disegala bidang ini sangat ditentukan oleh faktor manusianya yaitu manusia pembangunan yang bertaqwa, berkepribadian, jujur, ikhlas, berdedikasi tinggi serta mempunyai kesadaran bertanggung jawab terhadap masa depan bangsa disamping memiliki kecakapan dan keterampilan tinggi, menguasai ilmu pengetahuan dan teknologi maju (Ahmadi dan Salim, 2008).

Mengembangkan kemampuan tersebut perlu adanya lembaga pendidikan termasuk lembaga pendidikan Islam yang mampu mengarahkan dan membimbing manusia ke arah yang lebih baik. Pendidikan itu bisa berlangsung di sekolah, di rumah dan di lingkungan. Guru adalah tenaga pendidik di sekolah yang bertugas membantu proses belajar mengajar peserta didik dan sebagai pengembangan kurikulum. Adapun kurikulum menurut merupakan salah satu usaha yang dilakukan oleh sekolah untuk mempengaruhi belajar anak baik di dalam maupun di luar kelas. Menurut Nurdin (2005) struktur kurikulum yang dikembangkan mencangkup tiga komponen yaitu: (1) mata pelajaran, (2) muatan lokal, (3) pengembangan diri. 
Pengembangan diri adalah diri merupakan upaya pembentukan watak dan kepribadian peserta didik yang dilakukan melalui kegiatan pendidikan , bimbingan, pembinaan dan pengajaran. Pengembangan diri juga bertujuan untuk memberikan kesempatan kepada peserta didik untuk mengembangkan diri dan mengekspresikan diri sesuai dengan kebutuhan, potensi, bakat, minat, kondisi dan pengembangan peserta didik (Mulyasa, 2009). Kegiatan pengembangan diri merupakan upaya pembentukan watak dan kepribadian peserta didik yang dilakukan melalui kegiatan belajar dan pengembangan karir peserta didik. Pengembangan diri bagi peserta didik terutama ditujukan untuk pengembangan kreativitas dan bimbingan karir. Pengembangan diri yang dilakukan dalam bentuk kegiatan ekstrakurikuler dapat mengembangkan berbagai kompetensi dan kebiasaan peserta didik dalam kehidupan sehari-hari (Nurdin, 2005). Mulyasa (2009) menjelaskan bahwa kegiatan pengembangan diri merupakan upaya pembentukan watak dan kepribadian peserta didik yang dilakukan melalui kegiatan ekstrakurikuler berkenaan dengan masalah pribadi dan kehidupan sosial, kegiatan belajar, dan pengembangan karir peserta didik.

Pendapat para ahli di atas dapat dipahami bahwa pengembangan diri adalah kegiatan pendidikan yang berada di luar mata pelajaran dan upaya pembentukan watak dan kepribadian peserta didik. Kegiatan pengembangan diri tidak harus dilakukan guru tapi dapat juga difasilitasi dan dibimbing oleh konselor, kepala sekolah atau tenaga kependidikan lain yang memiliki kemampuan dalam membantu pengembangan diri peserta didik. Pengembangan diri juga meliputi kegiatan terprogram dan tidak terprogram. Kegiatan terprogram direncanakan secara khusus dan diikuti oleh peserta didik sesuai dengan kebutuhan dan kondisi pribadinya. Kegiatan tidak terprogram dilaksanakan secara langsung oleh pendidik dan tenaga kependidikan di sekolah/madrasah yang diikuti oleh semua peserta didik.

Program Pengembangan diri ini sesuai dengan Undang-Undang RI Nomor 20 Tahun 2003 tentang Sistem Pendidikan Nasional yang menegaskan bahwa pendidikan merupakan usaha sadar dan terencana untuk mewujudkan suasana belajar dan proses pembelajaran agar peserta didik secara aktif mengembangkan potensi dirinya untuk memiliki kekuatan spiritual keagamaan, pengendalian diri, kepribadian, kecerdasan, akhlak mulia, serta keterampilan yang diperlukan dirinya, masyarkat, bangsa dan negara, Pasal 1 butir (1). Konsep pendidikan ini, selanjutnya diperkuat dengan prinsip bahwa pendidikan diselenggarakan sebagai suatu proses pembudayaan dan pemberdayaan peserta didik serta berlangsung sepanjang hayat, pasal 4 ayat (3).

Selain itu, dalam pasal 4 ayat (4) Undang-Undang RI Nomor 20 tahun 2003 dinyatakan bahwa paradigma pengembangan diri yang harus dibangun adalah memberi keteladanan, membangun kemauan dan mengembangkan kreativitas dalam 
konteks kehidupan sosial kultural madrasah. Sehubungan hal tersebut, seperti yang dinyatakan dalam kerangka dasar kurikulum 2004 yaitu kegiatan pengembangan diri diselenggarakan secara berkesinambungan mulai dari pendidikan taman kanak-kanak (Raudhatul Athfal) sampai dengan pendidikan menengah.

Pembelajaran pengembangan diri secara khusus bertujuan agar peserta didik mampu menjalankan ajaran agama, menjadi kreatif, memiliki kemandirian, bersikap demokratis, sikap bertanggung jawab, sikap jujur. Mengembangkan bakat, minat, kompetensi dan kebiasaan dalam kehidupan, kemampuan sosial, kemampuan belajar, wawasan dan perencanaan karier dan kemampuan pemecahan masalah. Bentuk kegiatan pengembangan diri secara terprogram dilaksanakan dengan perencanaan khusus dalam kurun waktu tertentu melalui kegiatan ekstrakurikuler. Sedangkan untuk memenuhi kebutuhan peserta didik secara individual, kelompok dan atau klasikal melalui penyelenggaraan kegiatan pengembangan diri secara tidak terprogram dapat dilaksanakan sebagai berikut; rutin, spontan, keteladanan, dan kegiatan terprogram .

Jadi, pengembangan diri adalah sebuah upaya untuk mengembangkan dan mengekspresikan dirinya sesuai dengan kebutuhan, potensi, minat, dan bakat yang dimilikinya. Semua itu akan terwujud dari diri peserta didik dengan adanya dorongan dari dalam dan dari luar dirinya. Untuk mengekspresikan minat dan bakat peserta didik di sekolah, maka diadakan kegiatan pengembangan diri berupa kegiatan ekstrakurikuler.

Kegiatan kurikuler berarti rangkaian proses dalam dalam menyelenggarakan kurikulum pendidikan yang sedang diberlakukan atau dijalankan sebagai input pendidikan. Sedangkan kegiatan ekstrakurikuler merupakan kegiatan yang dilakukan dalam rangka mengembangkan aspek-aspek tertentu dari apa yang ditemukan pada kurikulum yang sedang dijalankan, termasuk yang berhubungan dengan bagaimana penerapan sesungguhnya dari ilmu pengetahuan yang dipelajari oleh peserta didik sesuai dengan tuntutan kebutuhan hidup mereka maupun lingkungan disekitarnya.

Ekstra kurikuler adalah kegiatan pembelajaran yang diselenggarakan di luar jam pelajaran yang disesuaikan dengan kebutuhan pengetahuan, pengembangan, bimbingan dan pembiasaan peserta didik agar memiliki kemampuan dasar penunjang. Ekstrakurikuler biasanya dilakukan secara terbuka dan lebih memerlukan inisiatif peserta didik sendiri dalam pelaksanaannya. Kegiatan ekstrakurikuler, peserta didik memiliki kebebasan penuh dalam memilih dan memilah bentuk-bentuk kegiatan yang sesuai dengan potensi dan bakat yang ada dalam dirinya dan sejalan dengan cita-cita pendidikan yang sedang ditekuninya. Dalam Panduan Kegiatan Ekstrakurikuler Pendidikan Agama Islam Departemen Agama RI (2005) dijelaskan bahwa kegiatan-kegiatan ekstrakurikuler peserta 
didik berarti melatih diri untuk menemukan jati dirinya yang sesungguhnya, dan belajar secara lebih dalam bagaimana mengaplikasikan pengetahuan yang didapatnya di kelas.

Pelaksanaan

kegiatan

ekstrakurikuler memerlukan perencanaan dan disesuaikan dengan kebijakan pendidikan atau sekolah yang bersangkutan, termasuk dukungan fasilitas, biaya dan tenaga pembina untuk kegiatan dan setiap pembina kegiatan ekstrakurikuler harus mempunyai kemampuan untuk membina peserta didik melalui kegiatan ekstrakurikuler. Kegiatan ekstrakurikuler keagamaan di lembaga pendidikan Islam merupakan kegiatan pembelajaran dan pengajaran di luar kelas yang mempunyai tujuan: 1). Meningkatkan pemahaman terhadap agama sehingga mampu mengembangkan dirinya sejalan dengan norma-norma agama dan mampu mengamalkan dlam perkembangan ilmu pengetahuan, teknologi dan budaya.. 2) Meningkatkan kemampuan peserta didik sebagai anggota masyarakat dalam mengadakan hubungan timbal balik dengan lingkungan sosial, budaya dan alam sekitar. 3) Menyalurkan dan mengembangkan potensi dan bakat peserta didik agar dapat menjadi manusia yang berkreativitas tinggi dan penuh karya.

Program ekstrakurikuler keagamaan pada umumnya dibagi menjadi dua jenis yaitu kegiatan wajib dan kegiatan pilihan. Kegiatan wajib adalah seluruh bentuk kegiatan yang berkaitan dengan masalahmasalah yang melibatkan potensi, bakat, pengembangan seni dan keterampilan tertentu yang harus didukung oleh kemampuan dasar yang dimiliki peserta didik. Sasaran program ini adalah seluruh peserta didik madrasah dan masyarakat sekolah, yang kegiatan ini wajib diikuti oleh seluruh peserta didiknya. Kegiatan pilihan adalah kegiatan yang ditetapkan sekolah berdasarkan minat dan bakat dari peserta didiknya.

Pada umumnya prinsip pelaksanaan kegiatan ekstrakurikuler keagamaan dilakukan di luar jam pelajaran, dan merupakan serangkaian program yang dapat menunjang dan dapat mendukung program intrakurikuler. Prinsip-prinsip program ekstrakurikuler adalah sebagai berikut: 1) Semua peserta didik, guru, dan personel administrasi hendaknya ikut serta dalam usaha meningkatkan program. 2) Kerjasama tim adalah fundamental. 3) Pembatasan-pembatasan untuk partisipasi hendaknya dihindarkan. 4) Prosesnya adalah lebih penting dari pada hasil. 5) Program hendaknya cukup komprehensif dan seimbang dapat memenuhi kebutuhan dan minat semua peserta didik. 6) Program hendaknya memperhitungkan kebutuhan khusus sekolah. 7) Program dinilai berdasarkan sumbangannya kepada nilai-nilai pendidikan di sekolah dan efisiensi pelaksanaannya. 8) Kegiatan ini hendaknya menyediakan sumber-sumber motivasi yang kaya bagi pengajaran kelas, sebaliknya pengajaran kelas hendaknya juga menyediakan sumber motivasi yang kaya bagi kegiatan peserta didik. 9) Kegiatan ekstrakurikuler hendaknya dipandang sebagai integral dari keseluruhan program pendidikan di sekolah, tidak sekedar tambahan atau 
sebagai kegiatan yang berdiri sendiri.

Agar lebih terarahnya penelitian ini maka pertanyaan penelitiannya adalah bagaimana pelaksanaan kegiatan ekstrakurikuler muhadharah dan kaligrafi dalam mengembangkan diri peserta didik Kelas VIII di MTsN Tapan Kabupaten Pesisir Selatan serta factor pendukung dan penghalangnya. Sedangkan tujuan penelitian adalah untuk menginformasikan bagaimana ekstrakurikuler muhadharah dan kaligrafi di MTsN Tapan sebagai lembaga pendidikan Islam dalam mengembangkan diri peserta didik.

\section{METODE PENELITIAN}

Jenis penelitian yang digunakan adalah penelitian kuaitatif yaitu penelitian yang bertujuan melakukan studi yang mendalam mengenai suatu unit sosial sedemikian rupa, sehingga menghasilkan gambaran yang terorganisir dengan baik dan lengkap mengenai unit sosial tersebut (Sugiyono, 2008). Metode penelitian ini menggunakan analisis deskriptif yang bertujuan untuk menggambarkan sesuatu apa adanya (deskriptif kualitatif). Menurut Sukardi (2003) penelitian deskriptif sebagai salah satu jenis penelitian yang bertujuan mendiskripsikan secara sistematis, faktual, dan akurat mengenai fakta-fakta dan mencoba menggambarkan secara detail. Peneliti berperan sebagai perencana, pelaksana, pengumpulan data, menganalisis, menyimpulkan dan akhirnya melaporkan hasil penelitian. Penelitian kualitatif deskriptif memerlukan sumber berupa informan, peristiwa, dan dokumen-dokumen terkait yang dipakai sebagai landasan untuk melakukan analisis (Yusuf, 2003).

Jenis data yang dikumpulkan adalah data primer dan data sekunder. Data primer, yaitu data yang diperoleh atau dikumpulkan langsung di lapangan oleh orang yang melakukan penelitian (Hasan, 2002). Data penelitian ini adalah data pelaksanaan kegiatan ekstrakurikuler muhadharah dan kaligrafi mengembangkan diri peserta didik kelas VII di MTsN Tapan Kabupaten Pesisir Selatan. Data di atas didapatkan dari sumber data primer yaitu sumber data yang diambil langsung dari responden atau subjek penelitian. Sumber data primer dalam penelitian ini adalah peserta didik dan seluruh guru pembina kegiatan ekstrakulikuler muhadharah, kaligrafi dan kepala sekolah.

Teknik pengumpulan data merupakan langkah yang paling strategis dalam penelitian, karena tujuan utama dari penelitian adalah mendapatkan data. Tanpa mengetahui teknik pengumpulan data, maka peneliti tidak akan mendapatkan data yang memenuhi standar data yang ditetapkan. Pengumpulan data dilakukan dengan menggunakan non-participan observation yang hanya mengamati untuk memperoleh data tentang pelaksanaan kegiatan ekstrakurikuler muhadharah dan kaligrafi dalam mengembangan diri peserta didik. Teknik kedua adalah wawancara yang digunakan untuk memperoleh keterangan dari Kepala Madrasah, guru pembina kegiatan 
ekstrakurikuler dan peserta didik untuk mendapatkan data pelaksanaan kegiatan ekstrakurikuler muhadharah dan kaligrafi dan faktor pendukung serta penghalang dalam mengembangkan diri peserta didik. Ketiga, teknik dokumentasi yaitu mencari data tentang pelaksanaan kegiatan ekstrakurikuler muhadharah dan kaligrafi dalam mengembangkan diri peserta didik - Sedangkan analisis penelitian ini menggunakan analisis deskriptif, naratif dan taksonomi.

\section{HASIL PENELITIAN PEMBAHASAN}

Pelaksanaan Kegiatan Ekstrakurikuler Muhadharah Dalam Mengembangkan Diri Peserta Didik

Beberapa bentuk program ekstrakurikuler di MTsN Tapan Kabupaten Pesisir Selatan, diantaranya adalah: Pertama, kegiatan Muhadharah. Muhadharah adalah pengungkapan pikiran dalam bentuk kata-kata yang ditujukan kepada orang banyak atau wacana yang dipersiapkan untuk diucapkan di depan khalayak, dengan maksud agar pendengar dari pidato tadi dapat mengetahui, memahami, menerima serta dapat diharapkan bersedia melaksanakan segala sesuatu yang disampaikan terhadap mereka, pidato juga merupakan seni berbicara di depan umum (Hadinegoro, 2007). Fungsi muhadharah adalah memberikan informasi, menghibur, membujuk, menarik perhatian, meyakinkan, memperingatkan, membentuk kesan, memberikan instruksi, membangun semangat.

Muhadharah merupakan kegiatan yang terprogram dan dibina oleh guru yang bertanggungjawab. Tujuan diadakan program ini untuk melatih peserta didik agar mampu mengekpresikan dirinya secara positif di depan umum, sehingga apabila nanti mereka kembali kemasyarakat, mereka mampu menghadapi realita bermasyarakat. Kegiatan muhadharah dilaksanakan secara bergiliran dalam penampilan.

Kegiatan muhadharah di madrasah ini dilakukan dengan perencanaan, pelaksanaan dan evaluasi. Perencanaan muhdarah dilaksanakan secara terprogram yaitu dilaksanakan dengan perencanaan khusus. kegiatan muhadharah dilaksanakan setiap minggu yaitu setiap hari selasa. Kegiatan ini dibina oleh guru pembina yang bertanggung jawab dalam pembelajaran kegiatan muhadharah. Muhadharah dilaksanakan setiap hari Selasa. Guru mempersiapkan secara umum apa-apa saja yang akan dilakukan dalam pelaksanaan kegiatan ekstrakurikuler muhadharah. Seperti persiapan waktu, materi atau tema, teknik, sarana dan prasarana terhadap peserta didik, serta memilih peserta didik yang tampil, sehingga pada saat pelaksanaan kegiatan muhadharah akan berjalan sesuai dengan tujuan yang diharapkan.

Pelaksanaan muhadharah dilaksanakan pada hari selasa pada jam 15.00-17.00, tempatnya di ruangan kelas, peserta didik menampilkan bakat sendiri ke depan, baik laki-laki maupun perempuan sesuai dengan tanggung jawab yang diberikan oleh pembimbing muhadharah. Teknik pelaksanaan kegiatan ekstrakurikuler muhadharah, adalah 
peserta didik menampilkan bakatnya sendiri ke depan, materi yang disampaikan terserah peserta didik apakah masalah akhlak, ibadah atau tauhid. Di sinilah guru juga melihat penampilannya dan bagaimana penyampaian dari isi ceramahnya. Penampilan ceramah ini di lihat pada saat kegiatan muhadharah yang diadakan hari Jum'at pagi. Pelaksanaan di hari Jumat sekaligus dijadikan kegiatan evaluasi kemampuan peserta didik (Syawaluddin, Pembina Muhadharah dan Guru Agama MTsN Tapan Kabupaten Pesisir Selatan, wawancara, Jum'at 16 September 2016).

Materi poidato yang akan disampaikan adalah materi yang berkaitan dengan masalah akhlak, ibadah atau tauhid. Materi yang disampaikan tersebut diserahkan sepenuhnya kepada peserta didik. Pada saat muhadharah pembimbing membawa buku-buku yang berhubungan dengan Islam dan materi yang disampaikan berdasarkan materi yang diminati oleh masing-masing peserta didik yang tampil pada saat muhadharah. Hal tersebut sangat membantu peserta didik dalam mengekpresikan dan mengembangkan dirinya dan mampu mengembangkan tema, sehingga mereka mengetahui serta memahami maksud dari kegiatan ini dan makna dari apa yang dibicarakan dan lakukan.

\section{Pelaksanaan Kegiatan Ekstrakurikuler Kaligrafi Dalam Mengembangkan Diri Peserta Didik}

Ekstrakurikuler kedua adalah kaligrafi adalah suatu ilmu yang memperkenalkan bentuk-bentuk huruf tunggal, letak-letaknya, dan tata cara merangkainya menjadi sebuah tulisan yang tersusun, atau apa-apa yang ditulis di atas garis-garis, bagaimana cara menulisnya dan menentukan mana yang tidak perlu ditulis, menggubah ejaan yang perlu diubah dan menentukan cara bagaimana untuk menggubahnya (Khoiri, 1999). D. Sirojuddin AR (1992) menjelaskan bahwa kaligrafi itu mempunyai makna tulisan yang indah, arti lainnya adalah kemampuan menulis indah atau elok (tulisan elok). Bahasa Arab tulisan indah itu disebut khat yang berarti garis atau disebut tulisan indah.

Menurut Aliman (2016), tujuan dari diselenggarakan kaligrafi diantaranya adalah: 1. Menciptakan rasa memiliki bagi peserta didik terhadap khazanah seni . 2 . Menghayati seni, dengan pemaknaan yang positif dan bermanfaat bagi kehidupan umat manusia.3. Menghidupkan syari'at Islam di lingkungan madrasah dan sekolah umum. Perencanaan ekstrakurikuler kaligrafi dilakukan dengan sistematik seperti waktu tempat pelaksana, teknik pelaksana materi, sarana prasarana, yang terlibat dan hasil terhadap peserta didik. Apabila salah satu sistem tidak terlaksana maka sistem ini akan terganggu. Tujuan dari kegiatan kaligrafi adalah untuk mengembangkan bakat dan minat peserta didik. Bagaimana peserta didik mampu untuk membuat tulisan yang indah sesuai dengan kaidah penulisan kaligrafi dan menciptakan suatu karya seni dan mengembangkan imajinasi dari peserta 
didik tersebut.

Kegiatan kaligrafi diadakan setiap hari Rabu pada pukul 14.00-16.00 wib dan dilaksanakan di ruangan kelas, karena madrasah belum mempunyai tempat khusus untuk melaksanakan kegiatan kaligrafi . kegiatan juga di lakukan luar sekolah yaitu di gedung ikhlas beramal KUA sanggar HIPSAL Tapan (Himpunan Pecita Seni Al-Quran). Kaligrafi dilakukan dalam bentuk kelompok tetapi dalam pembinaanya dilakukan dengan bentuk individual.

Selanjunya Firdauz (2016), Pembina Kaligrafi dan Guru Agama MTsN Tapan Kabupaten Pesisir Selatan menambahkan:

Syarat terlaksana kegiatan kaligrafi sehingga mencapai tujuan yang diharapkan adalah dengan memilikipelatih yang professional, yaitu guru MTsN memiliki keterampilan kaligrafi. Teknik dalam pembelajaran kaligrafi dengan menggunakan metode ceramah dan demontrasi dalam penyampaian materi, selanjutnya menekankan praktek menulis khat. Materi yang diberikan berupa,gambar-gambar kaligrafi huruf hijaiyah (khat) dan cara menulis model huruf-huruf hijaiyah. Guru memberikan materi dengan mendemontrasikan

cara menggambar di papan tulis, guru menulis huruf per hurufnya dengan perlahan-lahan sambil menjelaskan kepada peserta didik dan peserta didik disuruh untuk memperhatikannya. Kemudian guru menyuruh peserta didik untuk menirukannya di buku gambar mereka masing-masing dengan menggunakan dua pensil yang diikat menjadi satu selanjutnya peserta didik disuruh untuk menirukan.

\section{Faktor Pendukung dan Penghambat Pelaksanaan Kegiatan Ekstrakurikuler dalam Mengembangkan Diri Peserta Didik}

Setiap suatu kegiatan tertentu tidak terlepas dari permasalahan yaitu adanya faktor-faktor pendukung dan penghambat. Faktor pendukung adalah faktor pendorong terlaksananya kegiatan ekstrakurikuler. Sedangkan Faktor penghambat adalah kendala-kendala yang dihadapi dalam pelaksanaan kegiatan ekstrakurikuler. Faktor pendukung dan penghambat kegiatan muhadharah Kelas VIII di MTsN Tapan Kabupaten Pesisir Selatan.

Faktor pendukung kegiatan muhadharah adalah : Pertama, dukungan dan kebijakan dari Kepala Madrasah. Dukungan dari kepala madrasah sangat diperlukan oleh berbagai kegiatan yang berada di lingkungan tempat suatu kegiatan dilaksanakan, termasuk kegiatan muhadharah. Dukungan yang baik dari kepala madrasah atau pimpinan suatu lembaga akan menentukan hasil dari suatu kegiatan. Dukungan berupa perhatian, penyediaan anggaran, sarana dan fasilitas, dan memberikan pelatih yang professional. Kebijakan kepala madrasah seperti mewajibkan peserta didik untuk mengikuti muhadharah, juga sangat membantu sehingga semua peserta didik diberikan kesempatan yang sama dalam pengembangan diri; Kedua, 
guru/pelatih yang professional. Faktor pendukung kegiatan ekstrakurikuler muhadharah adalah dalam suatu kegiatan, kualitas guru/ pelatih menentukan hasil. Semakin profesional guru dalam membimbing suatu kegiatan akan semakin bagus kualitas peserta didik yang dihasilkan. Hal inilah yang menjadi pedoman menentukan guru pembimbing dalam melaksanakan kegiatan ekstrakurikuler keagamaan.

Faktor penghambat tercapainya tujuan muhadharah adalah: Pertama, sarana dan prasarana kegiatan muhadharah masih kurang. Seperti tempat latihan, sound system yang memadai, dan sebagainya; Kedua, peserta didik, masih kurang motivasi untuk berpidato pada diri peserta didik. Mereka masih ada yang malu malu berbicara di depan umum.

Terkait dengan kegiatan kaligrafi faktor pendukungnya adalah: Pertama, pembimbing yang professional. Pembimbing kaligrafi di madrasah ini terdiri dari beberapa pelatih yang professional, yang memiliki prestasi di bidang kaligrafi secara nasional. Oleh sebab itu keterampilan yang diberikan oleh pelatih sangat baik dan beragam; Kedua, peserta didik, berbeda dengan muhadharah, peserta didik yang mengikuti kaligrafi memiliki semangat dan motivasi yang tinggi untuk belajar. Hal ini dibuktikan mereka juga berprestasi di bidang kaligrafi tingkat kota dan provinsi. Meraka merasa memiliki perubahan yang besar dalam pengembangan diri.

$$
\text { Sedangkan faktor yang }
$$

menghambat kegiatan kaligrafi dalam mengembangkan diri peserta didik adalah: Pertama, alokasi waktu. Waktu yang sedikit yang dirasakan oleh peserta membuat mereka terkendala dalam mendalami kegiatan kaligrafi ini. Waktu yang disediakan sekolah, dirasa masih perlu ditingkatkan lagi seperti menjadi 3 kali seminggu. Karena kaligrafi merupakan perkerjaan yang lama, teliti, dan dilakukan dalam keadaan focus; Kedua, sarana dan prasarana kegiatan kaligrafi. Kegiatan bertempat di kelas dan kadang kadang di luar kampus menjadikan peserta didik kesulitan dalam latihan. Mereka mengharapkan adanya fasilitas khusus seperti sanggar yang disediakan sekolah. Perlengkapan kaligrafi yang tidak murah membuat beberap peserta didik mundur dari ekstrakurikuler kaligrafi. Diharapkan sekolah mampu menganggarkan alat lukis/khat, kertas, cat, kuas dan sebagainya sehingga peserta didik bisa mengikuti kegiatan.

Peran muhadharah dan kaligrafi dalam mengembangkan diri perserta didik tidak terlepas dari faktor pendukung sehingga kegiatan tersebut mencapai tujuannya. Faktor pendukungnya adalah dukungan penuh dari pimpinan madrasah, pelatih yang professional dan motivasi kuat peserta didik untuk serius dalam mengikuti kegiatan. Walaupun demikian, tentu ada hal hal yang menjadi kendala kegiatan ini. Factor yang menjadi kendala kegiatan ini adalah : fasilitas, sarana prasarana yang masih minim dan alokasi waktu yang 
sedikit. Berdasarkan factor pendukung dan kendala di atas, diharapkan pihak madrasah mampu mengatasi kendala sehingga kegiatan ekstarkurikuler di lembaga pendidikan ini dapat maksimal mengembangkan diri peserta didik.

\section{PENUTUP}

Berdasarkan hasil penelitian yang dikemukakan dalam pembahasan maka dapat diambil kesimpulan bahwa kegiatan ekstrakurikuler pada lembaga pendidikan Islam seperti lembaga pendidikan Islam Tsnawiyah dapat mengembangkan diri peserta didik. Pengembangan diri tersebut terlihat pada perubahan karakter dan sikap yang lebih baik. Ekstrakurikuler muhadharah dapat mengembangkan diri peserta didik sepertu menumbuhkan rasa percaya diri, komunikatif dalam menyampaikan materi, dan kreativ dalam memilih materi pidato yang sesuai dengan karakter pendengarnya. Sedangkan ekstrakurikuler kaligrafi dapat mengembangkan diri peserta didik menjadi pribadi yang sabar, teliti dan kreatif.

Sifat, sikap dan karakter yang merupakan hasil pengembangan diri peserta didik sebagai dampak dari kegiatan kaligrafi dan muhadharah ini, sangat diperlukan oleh peserta didik sebagai bekal hidup mereka di masa depan. Sifat kreatif, percaya diri, teliti, dan komunikatif merupakan sikap yang sangat diperlukan dalam mengimplementasikan ilmu mereka, dan merupakan sifat yang menunjukkan kecerdasan emotional yang $80 \%$ menentukan keberhasilan seseorang.

\section{DAFTAR PUSTAKA}

Ahmadi, Abu \& Noor Salimi, Dasar-Dasar Pendidikan Agama Islam, Jakarta: Bumi Aksara, 2008

Aliman, Pembina Kaligrafi dan Guru Agama MTsN Tapan Kabupaten Pesisir Selatan, wawancara langsung, Rabu 24 Agustus 2016

al-Maragy, Ahmad Mustafa, Terjemahan Tafsir Al-Maragy juz 28, Semarang : Toha Putra, 1974

AR, D.Sirojuddin, Seni Kaligrafi Islam, Bandung: Remaja Rosda Karya, 1992

Arifin, Muzain, Kapita Selekta Pendidikan, Jakarta: Bumi Aksara, 2008

DepartemenAgama RI, Panduan Kegiatan

Ekstrakurikuler Pendidikan Agama Islam, Jakarta: Direktorat Jenderal Kelembagaan Agama Islam, 2005 - Pedoman Kegiatan Pengembangan Diri, Jakarta: Direktorat Jenderal Kelembagaan Agama Islam, 2005

Hadinegoro, Luqman, Teknik Seni Berpidato Mutakhir, (Yogyakarta: Absolut,2007

Hasan, Iqbal, Pokok-Pokok Materi Metode Penelitian Dan Aplikasinya,Jakarta: Ghalia Indonesia, 2002

Khaerudin, dkk, Kurikulum Tingkat Satuan Pendidikan Konsep dan Implementasi di Sekolah, Yogyakarta: Nuansa Kasara, 2007

Khoiri, Ilham R, Al-Qur'an dan Kaligrafi Arab,Jakarta: Logos, 1999

Mulyasa E., Kurikulum Tingkat Satuan Pendidikan ( KTSP ), Bandung: PT: Remaja Rosdakarya, 2009 
Muslich, Masnur, KTSP (Kurikulum) Dasar-dasar Pemahaman dan Pengembangan, Jakarta : Bumi Aksara, 2008

Nurdin, Syafruddin, Guru Profesional dan Implementasi Kurikulum, Jakarta: Quantum Teaching, 2005

Ramayulis, Ilmu Pendidikan Islam, Jakarta: Kalam Mulia, 2004

Sugiyono, Metode Penelitian Pendidikan Pendekatan Kuantitatif, Kualitatif, dan RED, Bandung: Alfabeta, 2008
Sukardi, Metodologi Penelitian Pendidikan : Kompetensi dan Prakteknya, Jakarta: Bumi Aksara, 2003

Undang-Undang No 20 Tahun 2003, Undang-Undang tentang Sistem Pendidikan Nasional, Jakarta: Sinar Grafika, 2003

Yusuf, A. Muri, Metodologi Penelitian, (Fakultas Ilmu Pendidikan, IKIP Padang, 2003), h. 